19 Revue d'histoire du XIXe siècle

Société d'histoire de la révolution de 1848 et des

révolutions du XIXe siècle

$9 \mid 1993$

Utopies au XIXe siècle

\title{
Proudhon, Louis Blanc et Pierre Leroux : polémique sur la question de l'État
}

\section{Armelle Le Bras-Chopard}

\section{OpenEdition}

\section{Journals}

Electronic version

URL: http://journals.openedition.org/rh19/69

DOI: $10.4000 /$ rh 19.69

ISSN: 1777-5329

Publisher

La Société de 1848

\section{Printed version}

Date of publication: 1 June 1993

ISSN: 1265-1354

\section{Electronic reference}

Armelle Le Bras-Chopard, «Proudhon, Louis Blanc et Pierre Leroux : polémique sur la question de I'État », Revue d'histoire du XIXe siècle [Online], 9 | 1993, Online since 09 September 2008, connection on 01 May 2019. URL : http://journals.openedition.org/rh19/69; DOI : 10.4000/rh19.69

This text was automatically generated on 1 May 2019.

Tous droits réservés 


\section{Proudhon, Louis Blanc et Pierre Leroux : polémique sur la question de l'État}

Armelle Le Bras-Chopard

\section{ABSTRACTS}

No abstract available by now

Pas de résumé disponible actuellement

INDEX

Mots-clés: Histoire politique, Socialisme, Utopie, Etat, Histoire intellectuelle 